\title{
Proclus and the Liber de causis in Meister Eckhart's Works
}

\author{
Alessandra Beccarisi \\ Università del Salento
}

The scholar who, in sooth, does little else than handle books-with the philologist of average attainments their number may amount to two hundred a day-ultimately forgets entirely and completely the capacity of thinking for himself

F. NIETZSCHE, Ecce homo, New York, 2004 p. 48

\section{Introduction}

An author cannot be reduced to his library. Like any other "fact", an interpretation is necessary, by means of which the meaning and context of a quotation can be determined. I therefore agree with Dragos Calma ${ }^{1}$ when he denounces "les démarches cabalistiques de certaines études qui se contentent des nombres et des statistiques", because "une citation n' est jamais gratuite puisqu' elle présuppose un choix, une claire intentionnalité de la part de celui qui l'utilise. Savoir la faire résonner tient de la virtuosité interprétative de l'historien".

It is not easy to evaluate the importance of a source by taking into account one or more of these aspects: implicit, explicit, literal, non-literal, ad sensum, false attribution. ${ }^{2}$ The mere statistical data does not reveal the importance of a source. A single implicit quotation, even a non-literal one, can be at the heart of an original interpretation, and the historian must take this into account.

1 Calma 2010, p. Xv.

2 Bertolacci 1998, p. 261-339. 
On the other hand, the frequent use of "formulas" quoted literally and with mention of the author or work, may indicate the use of florilegia, which makes a quotation less significant than the simple statistical data may lead one to believe. A good exemple of this is Aristotle, and one of his works most quoted by Eckhart: De anima. According to the statistics, ${ }^{3}$ Eckhart cites this treatise about 300 times. Of these occurrences, however, more than half are reduced to brief sentences, not always literal, despite the mention of the author and the work. Yet if we relate this abstract statistical datum with the immediate context in which the quotation appears, and if we take into account the Eckhartian theory of the intellect, the interpretation might very well change. As far as philosophical interpretation is concerned, scholars admit a general distance of the Eckhartian doctrine from the Aristotelian one. ${ }^{4}$ Indeed, Eckhart, following the doctrine of Maimonides, recognizes Aristotle as der hoechste undern der meistern ${ }^{5}$ but only in the domain of the natural sciences, not in that of divine science. ${ }^{6}$

As far as works in Middle High German are concerned, things are remarkably complicated, for at least two reasons. The first is textual: quotations are often implicit, or explicitly indeterminate (to use Bertolacci's category ${ }^{7}$ ) or usually introduced by expressions such as ein meister, ein alter meister or ein heidnischer meister. Ein meister can refer to both a biblical authority or to a pagan master. ${ }^{8}$ The second reason is a linguistic one: the difference between citation ad litteram and citation ad sensum cannot be applied.

3 Calma 2009, p. 526; Beccarisi 2008, p. 11-12.

4 Beccarisi 2016, p. 223-240, with cited bibliographical references; see also Retucci 2012, p. 1137.

5 Meister Eckhart, Sermon 15 Q, DW I, p. 249,1 sgg.

6 Meister Eckhart, In Sap., n. 208, LW II, p. 542: Praedictis concordat quod Rabbi Moyses l. II c. 2, quod incipit 'Aristotele', sic ait: 'quidquid dixit Aristoteles in omnibus entibus, quae sunt a sphaera lunae usque ad centrum terrae, verum est sine dubio, nec repellit illud', 'nisi qui non intelligit'. 'Quidquid vero locutus est Aristoteles de his, quae sunt a sphaera lunae superius, est verisimile.' Et infra c. 25 dicit: 'Abubacer dubitat de verbis Aristotelis', 'et eius dubitatio est, utrum scivit Aristoteles egressionem centri sphaerae solis.' Et infra: 'quidquid dixit Aristoteles in omnibus, quae sunt sub sphaera lunae, procedit secundum ordinem sensus, et verba ipsius sequuntur ex ratione, et causa naturalis est manifesta in eis. Quidquid autem est in caelis, non est homo consecutus, ut sciret ea quae ibi sunt', adducens illud Psalmi: caelum caeli domino, terram autem dedit filiis hominum. 'Quod est dicere quod creator solus scit veritatem' eorum, quae in caelis sunt, in fine perfectionis. Super his autem, quae sunt sub caelis, dedit potestatem homini, ut sciret ea'. On Meister Eckhart and Maimonides cf. Di Segni 2012, p. 103140.

7 Bertolacci 1998, p. 261-339.

8 On Meister Eckhart's use of source cf. Vinzent 2014, p. 105-122; Sturlese 2008, p. 7-9. 
This is a good starting point for my contribution, concerning the influence of Liber de causis and Proclus on Meister Eckhart's thought. Since it is an argument already widely discussed in excellent studies, I will concentrate my attention on four examples.

The sermon $80^{9}$ is one of the few documents to explicitly quote Albert the Great. It represents the only occurrence within the context of Eckhart's entire production, in which he refers to the Liber de causis under the title Licht der Lichte, Lumen Luminum.

Eckhart aims at interpreting the passage "There was a rich man who was dressed in purple and fine linen and lived in luxury every day" (Luke 16:19). The parable of the rich man and Lazarus tells of the relationship between a rich man and a poor beggar named Lazarus. Their destinies are opposite as between them "stands a great abyss".

The rich man and Lazarus lead two totally opposite forms of existence. The goods of the rich man contrast with Lazarus's sufferings, but after death, their conditions are totally reversed. Indeed, Lazarus is released from the sufferings of his terrestrial existence, while the rich man is condemned to some sort of torment in Hades.

However, Eckhart seems almost uninterested in the content, as he only focuses on the opening line of the parable: "There was a rich man".

Eckhart seeks to comment on the word dives, which refers in particular to the reign of God, and which is manifested through five characteristics or aspects: ${ }^{10}$

The man was also 'rich'. So God is rich in Himself and in all things. Now note! The richness of God consists in five things.

The first: because He is the first cause; therefore He is pouring Himself into all things.

The second: because $\mathrm{He}$ is simple in His being; therefore $\mathrm{He}$ is the inwardness of all things.

9 On this Sermon cf. Geyer 1964, p. 121-126; Ruh 1996, p. 126-129; Retucci 20o8, p. 135-166, in particular p. 139-140; Goris 2009, p. 151-159, in particular p. 157; Bauchwitz 2016, p. 291-298; Beccarisi 2019, p. 38-41.

10 Meister Eckhart, Sermon 8o Q, DW III, p. 381,1 sgg.; English version by Vinzent 2019, p. 729733. I would like thank him for having made available unedited material. 
The third: because He is originating; therefore He is communicating Himself to all things.

The fourth: because $\mathrm{He}$ is unchangeable; therefore $\mathrm{He}$ is the most stable.

The fifth: because $\mathrm{He}$ is perfect; therefore $\mathrm{He}$ is the most desirable.

$\mathrm{He}$ is the first cause; therefore He is pouring Himself into all things. Of this a pagan master says that the primary cause pours itself out more into all causes than secondary causes pour themselves into their works.

He is also simple in His being. What is 'simple'? Bishop Albert says: Simple is the thing that is in itself one without a second, that is God, and all united things are by the fact that $\mathrm{He}$ is. There the creatures are one in the one and are God in God; by themselves they are nothing.

Third: because He is the originating [power], therefore He is flowing into all things. About this Bishop Albert says: In three ways he commonly flows into all things: with being, life and light, and especially into the intellectual soul by the potentiality of all things, and by a return of the creatures into their first origin: this is the light of lights, because 'every gift and perfection flow from the father of lights', as Saint James says.

Fourth: because $\mathrm{He}$ is unchangeable; therefore $\mathrm{He}$ is the most stable. Now note, how God unites Himself to things. He unites Himself with things and yet retains Himself as one in Himself, and makes all things one in Him. Of this Christ says: You shall be transformed into me, but not me into you. This derives from His immutability, His incommensurability and the smallness of things. About this a prophet says that all things compared to God are as small as a drop before the wild ocean. Whoever threw a drop into the ocean, the drop would transform itself into the ocean, but not the ocean into the drop. So it happens to the soul when she draws God into herself, she is transformed into God, so that the soul becomes divine, but God does not become the soul. Then the soul loses her name and her powers, but not her will and not her being. Then, the soul remains in God, as God remains in Himself. Of this Bishop Albert says: In the will, wherein a man dies, he will remain eternally.

Fifth, because He is perfect; therefore He is the most desirable. God is perfect with regard to Himself and to all things. What is perfection in God? It is that He is the good of Himself and of all things. Therefore, all things desire Him, because He is their good.

Sermon 8o, Homo quidam erat dives, exhibits three explicit references to Albert, the first two of which are significantly related to each other. Bernard Geyer, Kurt Ruh, Fiorella Retucci and Wouter Goris proposed that, in the Sermon Homo 
Quidam Dives, the Liber de causis plays a crucial role, albeit through the mediation of Albert's De causis et processu universitatis. In fact, in this work, Albert evaluates the different titles under which the Liber de causis circulated and offers a possible attribution.

The School of Avicenna-writes Albert-referred to it as the De lumine luminum (On the Light of Lights). In order to provide an explanation for this title, Albert affirms that the first cause flows into things in a threefold way: first there is an influence constitutive of being; then, there is an influence that produces virtue, and finally, a third type of influence that he calls influentia reductionis ad primum fontem. The second reference would also be, according to the interpreters, a quotation from Albert's De causis et processu universitatis.

In this case, it is an explanation of the term einvaltic (simplex), which is one of the five characteristics of the Divine. ${ }^{11}$

The exegetical tradition that claims that Eckhart was deeply influenced by the Neoplatonic tradition through Albert's mediation, seems hereby confirmed: the neoplatonic tradition that from Albert reached Bertothold of Moosburg via Eckhart, has at the same time established the importance of the Liber de causis in Meister Eckhart's work.

However, as I had the opportunity to demonstrate recently at the Lectio Albertina held at the Albertus Magnus Institut in Bonn, this is not the case. ${ }^{12}$

The source of Eckhart, in fact, is not Albert's Liber de causis et processu universitatis but rather Albert's Commentary on the Gospel of Matthew, as demonstrated by the following synopsis.
Albert the Great, Super Matth. c. 6,
Meister Eckhart, Pr. 8o, p. 382,9-
p. 181,81-182,8.21-29
$3^{84,5.6-386,3 ; ~ p . ~} 388,1-4$

Et secundum hunc intellectum in eo Diu rîcheit gotes diu liget an vünf dinquod dicit: qui es, quinque notantur, gen.

ens videlicet primum, simplex, fontale, immutabile, perfectissimum.

Ex primitate est influentissimum,

Daz êrste: daz er diu êrste sache ist, her umbe ist er ûzgiezende sich in alliu dinc.

\footnotetext{
11 Albert the Great, De causis et processu universitatis a prima causa, l. 1 tr. 1 c. 1, p. 61,16-22.

12 Beccarisi 2019.
} 
(cont.)

ex simplicitate communissimum et intimum,

ex fontalitate causalissimum,

ex immutabilitate conservantissimum,

ex perfectissimitate desideratissimum omnium.

Primum enim influit omnibus, et a nullo influitur ei, et est liberalitatis et magnificentiae profusae. Influit enim nullo indigens, et nullum aliorum aliquid alicui influere potest nisi per hoc quod accipit et habet $a b$ ipso. Et hic pater sic influens merito est orandus. Iac. I (17): 'Omne datum optimum et omne donum perfectum desursum est, descendens a patre luminum, apud quem non est transmutatio neque vicissitudinis obumbratio'. (...) Primum enim est, ut dicit Philosophus, quod influit, non supposito quodam alio, quod sibi det influere. Aristoteles: 'Causa primaria plus est influens quam secundaria'.

Per simplicitatem autem est communissimum et intimum, quia, sicut dicit Philosophus, quanto aliquid simplicius est, tanto in pluribus invenitur et sui ad plura indigetur.

[ex fontalitate causalissimum]
Daz ander: daz er einvaltic ist an sînem wesene, her umbe ist er diu innerkeit aller dinge.

Daz dritte: daz er ursprunclich ist, her umbe ist er gemeinende sich allen dingen.

Daz vierde: daz er unwandelhaftic ist, her umbe ist er daz behaldelîcheste.

Daz vünfte: daz er volkomen ist, her umbe ist er daz begerlîcheste.

Er ist diu êrste sache, her umbe ist er îngiezende sich in alliu dinc. Dâ von sprichet ein heidenischer meister, daz sich diu êrste sache mê gieze in alle die sache, dan die andern sache sich in ir werk giezen.

Er ist ouch einvaltic an sînem wesene. Waz ist einvaltic? Daz sprichet bischof Albreht: daz dinc ist einvaltic, daz an im selber ein ist âne ander, daz ist got, und alliu vereintiu dinc haltent sich in daz, daz er ist. Dâ sint die crêatûren ein in dem einem und sint got in gote; an in selben sint sie niht.

Daz dritte: daz er ursprunclich ist, dar umbe ist er ûzvliezende in alliu dinc. 
(cont.)

Albert the Great, De caus. et proc. univ.

1. 2 tr. 1 c. 1, p. 61,16-22

Lumen primae causae tripliciter influat rebus, scilicet influentia constitutionis ad esse et influentia irradiationis ad perfectionem virtutis et operis et influentia reductionis ad primum fontem ut ad boni principium, et huius influentia luminis omnis illuminationis principium sit et lumen, erit ipsum lumen luminum.
Hie von sprichet bischof Albreht: drîerhande wîs vliuzet er ûz in alliu dinc gemeinlîche: mit wesene und mit lebene und mit liehte und sunderlîche in die vernünftigen sêle an mügentheit aller dinge und an einem widerrucke der crêatûren in irn êrsten ursprunc:

Albert the Great, Super Matth. c. 6, p. 182,4-10.75-76; 183,6-10

Et hic pater sic influens merito est orandus. iac. i (17): 'Omne datum optimum et omne donum perfectum desursum est, descendens a patre luminum, apud quem non est transmutatio neque vicissitudinis obumbratio'. Non enim mutatur, ut quandoque fluat et quandoque non, neque vicissitudinem donorum recipit. ex immutabilitate conservantissimum (...) Immutabilitate fundat et continet et conservat ea quibus se influit. diz ist lieht der liehte, wan alle gâbe und volkomenheit vliezent von dem vater der liehte, als sant Jâcobus sprichet.

Daz vierde: daz er unwandelhaftic ist, dar umbe ist er daz behaldelîcheste. Nû merket, wie sich got vereinet mit den dingen. Er vereinet sich mit den dingen und beheltet sich doch ein an im selben, und alliu dinc an im ein. Hie von sprichet Kristus: ir sult gewandelt werden in mich und ich niht in iuch. Daz kumet von sîner unwandelhafticheit und von sîner unmæzlicheit und von der dinge kleinheit. 
(cont.)

Perfectissimum autem est hoc esse et ideo desideratissimum. Unde dicit Philosophus, quod 'omnia appetunt esse divinum et propter illud agunt, quidquid agunt'. Agg. II (8): 'Veniet desideratus cunctis gentibus'. Omnia enim istius patris desiderant superadventum. Sap. Ix: 'Omnia desiderabilia huic non valent comparari'. Esse enim datur ab eo, quo accepto nihil desideratur amplius, eo quod hoc est omnis naturae bonum et optimum. Exod. XXXIII (19.17): 'Ego ostendam tibi omne bonum; invenisti enim gratiam coram me'. In hoc est gaudium plenum, ut hoc comprehendamus, ut possumus. Ioh. XVI (24): 'Petite, ut gaudium vestrum sit plenum'. Matth. $\mathrm{V}$ (48): 'Pater vester caelestis perfectus est'.
Daz vünfte: daz er volkomen ist, dar umbe ist er daz begerlîcheste. Got ist sîn selbes volkomen und aller dinge. Waz ist volkomenheit an gote? Daz ist, daz er sîn selbes guot ist und aller dinge guot. Her umbe begernt sîn alliu dinc, wan er ir guot ist.

The evidence supporting this are: the five-part structure, the literal quotations of the five features of God, and the accuracy with which Eckhart translates the Albertinian text, going so far as to reproduce the superlative conservantissimum with behaldelîcheste and desideratissimum with begerlicheste.

A closer look reveals even more. In Sermon 8o, the quotation from the Liber de causis, attributed by Eckhart to a pagan master, corresponds in Albert's commentary to the same quotation attributed to the Philosophus (Aristotle), and in both cases it is used to comment on God's quality of 'firstness'.

Moreover, the famous licht der lichte would assume a completely different significance in this context when compared to Albert's text. Indeed, Eckhart says, I quote: "This is the light of light, because (wan in Middle High German) all gifts and perfection flow from the Father of light, as the Apostle James says". Hence, the First Cause is not (or not only) the "light of light", because Eckhart read Albert's commentary on the Liber de causis, but rather because he had in mind Albert's commentary on the Gospel of Matthew, in which the verse of St. James is quoted to express the fontalitas of God.

The discovery of this important new source from the Albert's commentary on the Gospel of Matthew reduces Kurt Ruh's claim that Eckhart "changed" his 
sources and rephrased them into his own words. ${ }^{13}$ In the German Sermons, Eckhart does not modify his sources, but he rather seeks to translate them as faithfully as possible.

That's why I am not convinced that two other quotations in the Sermon 8o, allegedly attributed to the Liber de causis, come in fact from this work:

Liber de causis prop. V n. 6o, p. $6 \circ, 35^{-40}$
Meister Eckhart, $P r$. Meister Eckhart, $P r$. 8o, DW III, 380, p. $2 . \quad 80$, DW III, 382, p. 5 .

Cum ergo res est causa tantum et non est causatum, non scitur per causam primam neque narratur quoniam est superior narratione, neque

got ist

überwesenlich und got ist überwesenlich und consequitur eam loquela. Quod est narratio non fit nisi per loquelam, et loquela per intelligentiam, et intelligentia per cogitationem, et cogitatio per meditationem, et meditatio per sensum. Causa autem prima est supra res omnes quoniam est causa eis; propter illud ergo fit quod ipsa

überredelich und überverstentlich, daz natiurlich verstân ist überlobelich und überredelich und überverstentlich non cadit sub sensu et meditatione et cogitatione et intelligentia et loquela. Non est ergo narrabilis.

Of the attributes describing God (überwesenlich, überredelich, überverstentlich), only überredelich shows a vague correspondence with the expression superior narratione. Thus it seems that Eckhart summarizes and rewrites proposition VI of the Liber de causis, to such an extent that we can say, as Dagmar Gottschall claims, ${ }^{14}$ that it is more a passage inspired by the Liber de causis rather than a quotation as such.

It is not surprising, therefore, to find this same quotation in another text, but with a different attribution. A pseudo-Eckhartian work, edited by Franz Pfeiffer, cites Dionysius instead of the Liber de causis: ${ }^{15}$

\footnotetext{
13 Ruh 1996, p. 127.

14 Gottschall 2015, p. 96.

15 Ps.-Eckhart, Tr. XI.2, 5o8,6 f. cited in Gottschall 2015, p. 97.
} 
Dionysius sprichet: diu êrste sache ist ob allen namen si ist überminnic, überweselich, überverstentlich, überredelich und übernâtûrelich.

The list of attributes is repeated almost identically to that found in Eckhart's Sermon 80: the differences are the addition of überminnic and übernâtûrelich, and the definition preceding those attributes (diu êrste sache ist ob allen namen), which is an important clue for the identification of Eckhart's source. The definition diuêrste sache ist ob allen namen could be both a quotation ad litteram of the proposition XXI of the Liber de causis (causa prima est super omne nomen quo nominatur), but also a quotation ad litteram from the second Letter from Saint Paul to the Philippians (Philipp. 2 (9) quod est super omne nomen) cited by Thomas Aquinas in the first chapter of his commentary to PseudoDionysius' De divinis nominibus.

So which one is Eckhart's source? I claim that neither Dionysius nor the Liber de causis, but rather Thomas Aquinas' Commentary on the Divine Names, as the following passage suggests: ${ }^{16}$

Deus, qui ipsa Unitas quasi existens unus per suam essentiam, quae est supersubstantialis (überwesenlich), superponitur substantiis et quae est super mentem superponitur mentibus, id est intellectualibus spiritibus; et ipsum Bonum, scilicet Deus, quod est super deliberationem, id est super omnem rationem, est indeliberabilis omnibus deliberationibus, id est non investigabile aliqua ratione creata (überverstentlich, daz natiurlich verstân ist) et quod est super verbum, id est super omnem locutionem creaturae (überredelich), est ineffabile, id est indicibile, omni verbo creato.

In this commentary to De divinis nominibus. Thomas Aquinas explains what super deliberationem means, i.e., "not susceptible of inquiry by any created reason" (non investigabile aliqua ratione creata) which corresponds, in my opinion, to daz natiurlich verstân ist in the German sermon.

Could the reference to the Liber de causis in German Sermon 80 be a "faux renvoi", to use Dragos Calma's definition? ${ }^{17}$ Hardly, it seems. The attribution to the Liber de causis is not entirely false, since the quotation seems in fact indebted to proposition XxI n. 166: "The First Cause is above every name by which it is named" (Causa prima est super omne nomen quo nominatur). ${ }^{18}$ The

16 Thomas Aquinas, Super div. nom. I 124.

17 Calma 2010, p. 8.

18 Liber de causis XXI n. 166, p. 93, 68-69. English translation by Brand 1984, p. 49. 
double attribution, and the fact that this quotation is documented three times in two different works, with the same phrasing, implies two hypotheses: the intermediate Eckhart's source is Thomas and Tr. XI.2 is a Eckhartian work.

In my opinion, the example confirms the observation from which we started, that is to say, the extreme fragility of statistical data alone, which must be considered with great caution, especially with regard to works in the vernacular.

I turn now to the heart of my contribution, based on the statistical data of Mario Meliadò, ${ }^{19}$ which corrects Fiorella Retucci's: ${ }^{20}$ the Liber de causis is cited 120 times, only ten of which appear in sermons in German. Proclus, on the other hand, is cited only twenty times.

Meliadò reports ${ }^{21}$ that of these 120 occurrences, Eckhart combines the authority of the Liber with that of Proclus in only five places. This approach distinguishes Eckhart from Dietrich of Freiberg, who frequently emphasizes the connection between the two authorities and underlines the dependence of the Liber on the Elementatio. On the contrary, Eckhart seems to prefer the Liber de causis to Proclus' authority, as I will try to demostrate. In particular I would like to show the great importance of proposition XV of the Liber de causis in Meister Eckhart's work. ${ }^{22}$

Despite its importance for Eckhartian speculation, the presence of proposition XV of the Liber de causis in his work does not seem to have aroused much interest among scholars. Its analysis is simply absent from the works of Kurt Ruh, Beierwaltes and Retucci, while Meliadò devotes to it only a note, in which he traces back the Eckhartian use of this proposition to Thomistic influence. ${ }^{23}$ Alain de Libera has studied abundantly the influence of proposition XV on Eckhart's thought, but by limiting it to the metaphysics of Exodus, that is, to the context of the Eckhartian interpretation of the first and only name of God: Ego sum qui sum. ${ }^{24}$

And yet proposition XV of the Liber de causis is one of the most quoted and, from my point of view, one of the most important. To the six occurrences recorded by Retucci and Meliadò, I would add two other quotations from the

\footnotetext{
19 Meliadò 2013, p. 506-507.

$20 \quad$ Retucci 2008, p. 155.

21 Meliadò 2013, p. 5 O7.

22 On the influence of proposition XV on Thomas Aquinas see Corrigan, Still 2004, p. 1-15; Putallaz 1991, p. 168-172; Baumgarten 2014, p. 23-47; Scarpelli Cory 2017, p. 185-229.

23 Meliadò 2013, p. 549, n. 178.

24 Libera 1996, p. 127-162, esp. p. 151-162.
} 
commentary on Exodus, and one another from the German Sermon 15, that I am going to discuss later (see below, p. 363):

1. Tertio notandum quod repetitio, quod bis ait: 'sum qui sum', puritatem affirmationis excluso omni negativo ab ipso deo indicat; rursus ipsius esse quandam in se ipsum et super se ipsum reflexivam conversionem et in se ipso mansionem sive fixionem. ${ }^{25}$

2. Sic ergo 'bonum bonum' significat bonum impermixtum et summum bonum in se ipso fixum, nulli innitens, super se ipsum 'rediens reditione completa'. Sic li ‘sum qui sum' impermixtionem esse et eius plenitudinem indicat, ut dictum est supra. ${ }^{26}$

Eckhart quotes proposition XV in full and literally only once, in the commentary on the Gospel of St. John: ${ }^{27}$

Ergo et deus nusquam proprius, sed nec proprie invenitur aut noscitur nisi in se ipso. Hinc est quod oculus non videt nec noscit se, quia non potest redire supra se. Et in De causis dicitur quod 'omnis sciens, qui scit essentiam suam, est rediens ad essentiam suam reditione completa'.

As Therese Scarpelli recently showed, this proposition is known in two variants, both documented by Thomas Aquinas. The first variant ("Every knower who knows his essence returns to his essence with a complete return"-Omnis sciens qui scit essentiam suam est rediens ad essentiam suam reditione completa) appears in Thomas Aquinas' Commentary on the Sentences and in his Summa, while the second Variant B ("Every knower knows his essence, therefore he returns to his essence with a complete return"-Omnis sciens scit essentiam suam, ergo est rediens ad essentiam suam reditione completa) appears for the first time in Thomas Aquinas' commentary on Liber de causis. ${ }^{28}$

As the passage from the commentary on the Gospel of St. John clearly shows, Eckhart uses only the first variant (Omnis sciens qui scit essentiam suam est rediens ad essentiam suam reditione completa), suggesting that his source is not Thomas Aquinas' commentary on Liber de causis. I will return to this point after.

In the other seven instances, Eckhart quotes literally only the formula reditione completa, within the account of the features of the substance reverting upon its own essence: "that it is subsistent, stable in itself, not in need of a

\footnotetext{
25 Meister Eckhart, In Ex. n. 16, LW II, p. 21,7.

26 Meister Eckhart, In Ex. n. 17, LW II, p. 23,5.

27 Meister Eckhart, In Ioh. n. 222, LEW III, p. 186,9-13.

28 Scarpelli Cory 2017, p. 207-214.
} 
support for its stability and its essence, because it is a simple, self-sufficient substance"29 (quia es stans, fixa per se, non indigens in sua fixione et sui essentia re alia rigente ipsam, quoniam est substantia simplex, sufficiens per se ipsam).

As for the contexts in which it is used by Eckhart, proposition $\mathrm{XV}$ is cited when dealing with three main subjects: 1 ) to describe the internal dynamics of the One-mostly in the commentary to Exodus - associated to the concept of negatio negationis (self-identity); 2) when introducing one of his most wellknown neologisms in vernacular, namely the adjective istic and the substantive Isticheit, the basis for which seems to be, in fact, the concept of reditio completa; 3 ) with reference to the metaphysics of the intellect (self-determination)

There is no mention of Proclus in Eckhart's German Sermons. I do not agree with Retucci, who assumed that the negatio negationis (the Latin version of versagens des versaggenes), which appears in German Sermon 21, derives from Proclus' commentary on Parmenides, ${ }^{30}$ translated by Moerbeke. This is quite unlikely for three reasons.

First of all, in his Prologue to the Opus Tripartitum, when explaining the verse Deus unus est, Eckhart affirms that this is supported by the authority of Proclus and the Liber de causis. Furthermore (Preterea)-Eckhart adds-God is negatio negationis. Evidently Eckhart doesn't link the negatio negationis to Proclus: ${ }^{31}$

Rursus eodem modo se habet de uno, scilicet quod solus deus proprie aut unum aut unus est, Deut. 6: 'deus unus est'. Ad hoc facit quod Proclus et Liber de causis frequenter nomine unius aut unitatis deum exprimunt. Praeterea li unum est negatio negationis. Propter quod soli primo et pleno esse, quale est deus, competit, de quo nihil negari potest, eo quod esse omnia simul praehabeat et includat.

Secondly, the expression negatio negationis never appears in Proclus' commentary. Moreover, the expression circulated before Moerbeke's translation, for instance in the works of Henry of Ghent. ${ }^{32}$ As Wouter Goris has shown,

29 Liber de causis, prop. XV, n. 128, p. 79,65-8o, 67-69. English translation by Brand 1984, p. 48.

3० See Retucci 2008, p. 151-154.

31 Meister Eckhart, Prol. Op. Trip. n. 6, p. 44.

32 Henricus de Gandavo, Summa quaestionum ordinariarum, a. 25, q. 1, fol. 148rE. The influ- 
according to Henry of Ghent the negatio negationis serves to admit unity as something posited in the divine. The attribution of unity to God is conceived in terms of something which is added to the existent. The negatio negationis forms the explication of an indivisio that is predicated of the One as an additional modus significandi. In his Summa, in response to the objection that 'the One' is employed not as a positive but as a private designation in the Godhead, Henry of Ghent replies by stating that the negatio negationis is a verissima positio, in a sense very near to the Eckhartian position on the negatio negationis.

The third reason is based on the refutation of Retucci's argument, according to which, there are different uses of the notion of negatio negationis between Eckhart's Latin and German works: ${ }^{33}$

In Eckhart vi sono due impieghi ben differenti e circostanziati della negazione della negazione, come già de Libera aveva notato. Fino ad un certo punto, infatti, l'attribuzione negativa dell'uno rimane in Eckhart una teoria dell'uno trascendentale in cui non si possono non ravvisare gli echi della speculazione metafisica di Enrico di Gand, come già Goris ha sottolineato. In tutte le sue esposizioni enologiche, essenzialmente concentrate nella predicazione tedesca, Eckhart supera la prospettiva ontologico-trascendentale dell'opera latina. E ciò avviene, a mio avviso, proprio nella direzione della prima ipotesi del commento al Parmenide di Proclo. Nella predicazione in volgare Dio è negazione della negazione, in quanto Uno trascendente e non in quanto essere.

I do not believe that Eckhart's German output presents a different perspective than his Latin work. Nor do I believe that in his Latin work Eckhart speaks of the One in an ontological-transcendental perspective, whereas in the German work he speaks of the One as transcendent beyond Being.

I start my analysis with a passage from German Sermon 21, ${ }^{34}$ in which the expression versagenes des versaggenes is presented:

Saint Paul says: 'One God'. One is somehow more pure than goodness and truth. Goodness and truth do not add anything, they add in a thought; when something is thought, it is added. One does not add anything, as $\mathrm{He}$

ence of Henry is noted by Goris 1997, p. 197-206, esp. p. 200; on the provenance of negatio negationis see also Hedwig 1980, p. 7-33; Steel 1999, p. 351-368; Beierwaltes 1972, p. 42; Id. 1998, p. 100-129, esp. p. 112-119; Tsopurashvili 2012, p. 200; Enders 2012, p. 366-369.

33 Retucci 2008, p. 155.

34 Meister Eckhart, Sermon 21, DW I, 363, 7-8. English version by Vinzent 2019, p. 791-793. 
is in Himself, before He emanates into the Son and the Holy Spirit. So He said: 'Friend, lift yourself up.' A master says: One is a negation of negation. If I said: God is good, it would be adding something. One is a negation of negation and a denial of denial. What is the meaning of 'one'? 'One' means that nothing is added to it. The soul takes theGodhead as it is purified in her, where nothing is added, where nothing is thought about. One is a negation of negation. All creatures have a negation in them; 'one' negates being the other. 'One' angel negates being another. But God has a negation of negation; $\mathrm{He}$ is one, and negates anything else, because there is nothing except God. All creatures are in God and are of His own Godhead; and this means fullness, as I have already said. He is a Father of the whole godhead. For this reason, I say 'one' Godhead, where no emanation has taken place and nowhere is anything touched or thought about. By denying anything to God-I deny the goodness of God, even though I cannot deny God-, by denying to God, I grasp something of Him that He is not; this must go. God is one, He is a negation of negation.

For it to be correctly understood, this passage needs to be placed in its proper context. Eckhart quotes, as was stated, the words of a master, who declares that the One is negation of negation. Eckhart then explains what he understands by this expression: God is One, and he denies everything else because nothing is outside of God, whereas all things created are in God, and are His very Godhead. Thus, it is not possible to say of God that He is 'not something', as if He were any other creature. God, insomuch as He is One, contains in Him everything and this "means plenitude" (meinet ein vüllede), as he has already stated (als ich $\hat{e}$ sprach). Sturlese claims ${ }^{35}$ that this self-reference refers to another passage of Sermon 21, in which Eckhart is in fact speaking about God in terms of plenitude. The passage identified by Sturlese is the following: ${ }^{36}$

God has all things in Himself in fullness; for that reason, He does not seek anything outside of Himself, if not in fullness as it is in God. As God bears it within Himself, no creature can grasp.

As is clear, however, this passage pointed out by Sturlese does not include any reference to the negatio negationis as the sign of this plenitude.

35 Sturlese 2014, p. 832, note 13.

36 Meister Eckhart, Sermon 21, DW I. English version by Vinzent 2019, p. 789 . 
But Eckhart has in fact proposed elsewhere the idea that the concept of negatio negationis means (meinet) a plenitudo. I refer to the Commentary on St. John's Gospel: ${ }^{37}$

In ea, scilicet divina natura, est omnis negationis negatio, consequenter nulla prorsus imperfectio, defectus, sed plenitudo esse, veritas et bonitas.

In the Latin commentary we find then the same concept expressed in Sermon 21: the One is the negation of every negation, because in itself it already has everything. There is nothing outside of Him: it is not possible to say that the One, or rather God, is not Goodness, because there is nothing that can be denied of God, insofar as He is One, because He contains already everything in His self. This is then the true sense of the passage in the German Sermon 21: when I deny something of God (for instance, I deny of Him Goodness), I understand something about Him, namely, that He is not a determined Goodness. But this (the negation that God is something) must be eliminated. That which must be eliminated, then, is not simply the fact that I understand something (dâ begrîfe ich etwaz von im) as Retucci argues, ${ }^{38}$ but rather the grasping "at something in Him that He is not". How can I in fact grasp divine plenitude by simply denying attributes? What Eckhart says is that a simple negation must be avoided: insofar as He is One, insofar as He is plenitude, God denies (forbids) negation. ${ }^{39}$ If God is plenitude, it is possible neither to deny nor to add anything to Him. It is not possible to deny Him anything because He is, in fact, plenitude.

In Sermon 21, then, Eckhart does not present a sense of a transcendent One that is different from that in his Latin work, but simply repeats what was stated many times: regarding God and the divine it is not true, as Pseudo-Dionysius says, that negationes sunt verae, affirmationes incompactae: ${ }^{40}$

'Omnipotens nomen eius'.

Ibi habes primo breviter et luculenter quae deus possit et quae aut qualia non possit vel potius dicatur non posse a vulgaribus. Habes etiam ibidem plura de nominibus, quibus deus nominatur in scriptura, a philosophis, a sanctis et doctoribus, et quomodo sola substantia et relatio secundum genus suum admittuntur in divinis, et quomodo affirmationes sunt

Meister Eckhart, In Ioh. n. 692-693, LW III, p. 6o8, 10-p. 6o9, 1.

38 Retucci 2008, p. 151.

39 On this passage see also the interpretation of Beierwaltes 1998, p. 112-113.

40 Meister Eckhart, In Ex. Tabula Auctoritatum, DW II, p. 3,1-8. 
propriae in divinis, negationes autem impropriae. Nec obstat verbum Dionysii dicentis quod negationes in divinis sunt verae, affirmationes autem incompactae.

There does not seem then to be any difference between what Eckhart affirms in his Latin and German works. A comparison between Sermon 21 and Latin works in fact shows a substantial uniformity (similar notions in bold):

In Sap. n. 148, 486,2-3

Iterum etiam li unum nihil addit super esse, nec secundum rationem quidem, sed secundum solam negationem; non sic verum et bonum. (...)

Significat enim li unum ipsum esse insuper in se ipso cum negatione et exclusione omnis nihili, quod, inquam, nihil omnis negatio sapit

\section{Sermon 21 Q}

Ein ist etwaz lûterz dan güete und wârheit. Güete und wârheit enlegent niht zuo, sie legent zuo in einem gedanke; dâ ez bedâht wirt, dâ leget ez zuo.

Ein enleget niht zuo, dâ er in im selber ist, ê er ûzvlieze in sun und heiligen geist.

In Sap. n. 148, 486,

Sermon $21 \mathrm{Q}$

Omne citra deum, utpote citra esse, est ens et non ens, et negatur sibi aliquod esse cum sit sub esse et citra esse, et ideo ipsi congruit negatio.

Alle crêatûren hânt ein versagen an in selben; einiu versaget, daz si diu ander niht ensî (...)

In Ioh. n. 208, 176,1-5 Sermon $21 \mathrm{Q}$

'Deus enim unus est': in uno autem non est magis et minus, sed nec distinctio nec creatum ens hoc et hoc. Rursus nec proprium; unum enim sicut ens commune est omnibus. Adhuc autem in uno, ut unum est, non cadit malum, defectus, deformitas, privatio, sed neque negatio nisi negationis; unum enim negat divisionem et numerum et esse multum.
Aber got hât ein versagen des versagennes; er ist ein und versaget alle ander, wan niht ûzer gote enist. 
(cont.)

In Ioh. n. 692-693, 6o8-6o9

Sermon $21 \mathrm{Q}$

Proprietas divinae naturae increatae

Alle crêatûren sint in gote und sint sîn est unitas et per consequens immobselbes gotheit und meinet ein vüllede, ilitas, immutabilitas et quies; nulla ibi als ich ê sprach.

negatio nec per consequens multitudo, quin immo est in ea omnis negationis negatio, consequenter nulla prorsus imperfectio, defectus, sed plenitudo esse, veritatis et bonitatis.

In Ioh. n. 562, 489,8-10

Sermon $21 \mathrm{Q}$

Propter quod sancti unum sive unitatem Er ist ein vater aller gotheit. in divinis attribuunt primo supposito sive personae, patri scilicet.

In Ex. n. 77, 8o,9-11

Sermon $21 \mathrm{Q}$

Negationes ergo dictae de deo hoc solum ostendunt quod nihil istorum, quae in rebus extra sunt et quae sensibus apprehenduntur, in deo est. Patet igitur quod affirmatio, utopote ad esse pertinens, propria est Deo et divinorum, in quantum divina sunt. Negatio autem non est propria, sed aliena a Deo (...) quia affirmatio esse habet et includit
In dem daz ich gote versage etwaz, versage ich gote güete, ich enmac gote niht versagen - in dem daz ich gote versage, dâ begrîfe ich etwaz von im, daz er niht enist; daz selbe muoz abe. Got ist ein, er ist ein versagen des versagennes.

According to Eckhart, 'One' means 'pure Being' insofar as the One is the negation and exclusion of any 'nothing' that implies a negation. The One is then the highest negation, because it is the Being without negations, or rather Being itself: as Eckhart states in his Sermon 21, da er in im selber ist. Every negation, in fact, denies any being, and this lack of being is expressed by the word negatio. The negation of the negation, then, which is the meaning of the One, tells us that such a concept includes in itself everything that belongs to it and excludes on the other hand that which does not belong to it, namely 
non-being. The One to which Eckhart refers is not then the One defined by Proclus, at least not in the sense found in his Commentary on Plato's Parmenides. ${ }^{41}$ Eckhart connects in fact the negatio negationis with the self-revelation ego sum qui sum as a specific representation of the 'One' as purum esse in se ipso (which corresponds to the expression er in im selber ist in German Sermon 21) and as pure self-affirmation on the basis of the authority of the Liber de causis as the following passage of the Commentary on Exodus suggests: ${ }^{42}$

Nulla enim propositio propter hoc est verior illa, in qua idem praedicatur de se ipso. Omne citra deum, utpote citra esse, est ens et non ens, et negatur sibi aliquod esse cum sit sub esse et citra esse, et ideo ipsi congruit negatio. Ipsi autem esse non negatur aliquod esse, sicut animali non negatur hoc animal, puta leo. Nulla ergo negatio, nihil negativum deo competit, nisi negatio negationis, quam significat unum negative dictum: "deus unus est," Deut. 6; Gal. 3. Negatio vero negationis purissima et plenissima est affirmatio: "ego sum qui sum." Super se ipsum "redit reditione completa", sibi ipsi innititur, se ipso est, ipsum esse est. Nulla ergo negatio deo congruit: "se ipsum negare non potest," Tim. 2.

Eckhart also calls the intellectual self-positing and self-affirmation of God "negation of the negation," since it is a pure and utterly complete self-affirmation that abolishes all the limitations, and thus every negativity, of the creaturely existent: "I am who I am." Since the truth of an affirmative proposition consists in general in the identity of its terms, the self-affirmation that is the plenitude of pure Being itself is characteristic of God; it is this self-affirmation that utters itself in His name "I am who am". This is why this tautological sentence is the truest of all sentences.

41 I subscribe therefore to Beierwaltes's position, who claims (Beierwaltes 1965, p. 396): "Während bei Proklos die Negation der Negation in die Aufhebung affirmativer und negativer Dialektik in Glauben und Schweigen führt, ist die negatio negationis bei Eckhart Ursprung reiner Affirmation negatio vero negationis purissima et plenissima est affirmatio: ego sum qui sum. Negatio negationis ist also nicht wie bei Proklos der äußerste Akt des sich selbst übersteigenden Denkens, das den nicht-denkenden und nicht zu denkenden Ursprung zu berühren versucht, sondern der Selbstvollzug des reinen Seins als Denken". Vinzent subscribed to the same position in Vinzent 2012, p. 43, n. 139: "Proclos is not affirmative, however, when he writes about the 'indistinctness' of the One or the negation of negation, whereas for Eckhart life, affirmation, creativity and God's 'outgoing' are key".

42 Meister Eckhart, In Ex. n. 74, 77,9-78,2. 
This self-revelation is therefore not static, but dynamic. For, in this selfreflexive act, God returns with a perfect act of returning to His own self, as Eckhart states in agreement with proposition $\mathrm{XV}$ of the Liber de causis.

This means that Eckhart uses proposition XV of Liber de causis in order to explain the meaning of negatio negationis: God, insofar as He is One, is a dynamic identity reverting upon himself, which excludes every negation of himself.

Now, in his German output, Eckhart has coined a specific terminology for indicating this property of the One eternally converted upon itself, that is Isticheit, a self-reflecting identity in himself. This neologism appears mostly in contexts in which Eckhart deepens the theory of union between God and human soul and of the intellectual ground of this union as the following two passages document. ${ }^{43}$

The first is a passage in German Sermon 12, in which Eckhart describes the rapture of St. Paul in terms of a renunciation of the greatest good, that is God itself ("I renounce God for God's sake"). But at the same moment that Paul renounces to God as a subject opposed to him, he properly remains in God, who is istic sin selbes, that is identical reflection on Himself of Himself. At this level, all determinations must necessarily disappear, even the most general ones. Here, in this state, it is not possible to distinguish between creature and God whom one has already renounced. There is only immutable unity and perfect identity, the One: ${ }^{4}$

St. Paul left God for God: he left everything that he could get from God, he left everything that God could give him and everything he might receive from God. In leaving these, he left God for God, and then God was left with him, as God 'is an identical reflection on Himself of Himself' (dâ got istic ist sin selbes), not by way of a reception or a gaining of Himself, but rather in an 'identity reverting upon ist own essence' (denne in einer isticheit), 'that is where He is in Himself', (daz got in im selber ist). He never gave God anything, nor did he receive anything from God: it is a single oneness and a pure union (...) It is one, it has nothing in common with anything, and nothing created has anything in common with it.

43 On this neologism see Beccarisi 2003, p. 328-358.

44 Meister Eckhart, Sermon 12 Q, DW I, p. 197, 2-6. English version by Walshe in Walshe, McGinn 2007, p. 296-297. I've changed the translation slightly by highlighting it with English quotation marks. See also the Foreword to Walshe's translation by McGinn in Walshe, McGinn 2007, p. XVIII. 
The second passage is taken from the German Sermon 77, in which Eckhart comments on the pronoun "I" (ich): God as One, that is as the absolute unity itself, excludes from Himself any negative, that is every non-being according to the form of otherness, He affirms Himself as pure being in itself. Selfaffirmation as self-proclamation of the pure being-one must be understood as a self-identity (isticheit): 45

As regards the other sense: where the text says, 'I', that means in the first place God's self-identity (isticheit) the fact that God alone is, for all things are in God and from Him, since outside of Him and without Him nothing truly is: all creatures are worthless and a mere nothing compared with God. Therefore, what they are in truth they are in God, and thus God alone is in truth. And therefore the word 'I' means the self-identity of divine truth, for it is the proof of one is. It thus testifies that He alone is.

This passage matches almost literally the text from the Exodus commentary, analysed above, where we find a clear connection between the One as negatio negationis, the metaphysics of Ego sum qui sum understood as the purest repetition and affirmation, and proposition $\mathrm{XV}$ of the Liber de causis expressed in the German output with the term isticheit.

In the next part of my contribution I will show how the concept of conversio or reditio affects Eckhart's thought on self-knowledge and self-determination.

\section{The reditio completa as Foundation of Self-Determination}

I will begin with German Sermon 9 Q ${ }^{46}$ Quasi stella matutina, a very famous sermon in which Eckhart establishes the superiority of the intellect over will and esse. The composition of this sermon should be dated to the period of the first Parisian magisterium (1301-1302). At the same time, three questions, together with the so-called Rationes Equardi held by Eckhart against the Franciscan Gonsalvus of Spain, have been devoted to the subject of the superiority of the intellect. The German sermon takes up several arguments that Eckhart had used in both the questions and the dispute against Gonsalvus. One of them considers the intellect's ability to convert upon itself and to act inwardly: ${ }^{77}$

45 Meister Eckhart, Sermon 77 Q, DW III, p. 339, 1-6. English version by Walshe in Walshe, McGinn 2007, p. 263.

46 This sermon has recently been commented upon by Flasch 2017, p. 1-28.

47 Meister Eckhart, Sermon 9 Q, DW I, p. 157, 8-158, 5. English version by Walshe 2007, p. 345. 
Intellect always works inward. The subtler and more spiritual a thing is, the more strongly it works inwardly; and the stronger and finer the intellect is, the more is that which it knows united with it, the more it becomes one with it. It is not thus with physical things: the stronger they are, the more they work outward. God's blessedness lies in the inward-working of the intellect in which the Word is immanent.

We find the same argument, with almost the same words, in the so-called Rationes Equardi:48

Sed intellectus et intelligere maxime est immune a materia, quia tanto aliquid est minus reflexivum quanto materialius. Reflexio autem non est in essendo, sed in intelligendo.

In both texts Eckhart demonstrates the superiority of the intellect as such, not only over the will but also over determinate being. The reason for this superiority is its capacity to "work inwardly," in the Latin text indicated by the term reflexio and in the German sermon by the expression inwert würkende. The difference between spiritual substance, which can convert to itself, and material substance, which, on the contrary, cannot convert to itself, finds its origin, as we know, in Proclus. ${ }^{49}$

Eckhart's intermediate source, however, is not Proclus, but rather Thomas Aquinas, who in his Summa contra gentiles states: ${ }^{50}$ Intellectus autem supra se ipsum agendo (würkende) reflectitur; intelligit enim seipsum.

Furthermore in his commentary to the Liber de causis, analyzing proposition VII n. 68 (Et significatio quidem illius est reditio sui super essentiam suam, scilicet quia non exenditur cum re extens), ${ }^{51}$ Thomas mentions two propositions from Proclus in order to describe the reversion of the intellectual substance upon its own essence: 52

Et primo prosequitur de incorporeitate sic dicens: 'quod quidem igitur incorporeus sit Intellectus, quae ad se ipsum conversio manifestat', est autem conversio intellectus ad se ipsum in hoc quod seipsum intelligit; 'corporum enim nullum ad se ipsum convertitur'. Et hoc quidem

48 Rationes Equardi in Bibliotheca Eckhardiana Manuscripta p. 5o, 35-37.

49 On this topic see Steel 2006, p. 230-255.

$5^{\circ} \quad$ Thomas Aquinas, Summa contra gentiles II 498.

$5^{1} \quad$ Liber de causis, prop. viI n. 68, p. 62,81-83.

$5^{2}$ Thomas Aquinas, Super Librum de causis expositio, p. 51, 23-29. 
supra probaverat praemittens XV propositionem talem: 'Omne quod ad se ipsum conversivum est, incorporeum est'.

Thomas explicitly links the conversio described by Proclus to the reditio of the Liber de causis, thus establishing a terminological indetermination which we then find in the works of Meister Eckhart. Eckhart himself speaks primarily of reditio and reflexio, and much less frequently of conversio, even in cases where he explicitly quotes Proclus, as the following examples make clear: ${ }^{53}$

Cum enim videat, est in se tamen invisibilis, utpote non coloratus; item quia alio oculo indigeret; item, quia, cum sit corpus, super se redire non potest, ut Proclus docet.

Though Eckhart mentions Proclus explicitly, the expression super se redire derives from the Liber de causis, as documented by an analogous passage from the commentary to the Gospel of John: ${ }^{54}$

Ergo et deus nusquam proprius, sed nec proprie invenitur aut noscitur nisi in se ipso. Hinc est quod oculus non videt nec noscit se, quia non potest redire supra se. Et in De causis dicitur quod 'omnis sciens, qui scit essentiam suam, est rediens ad essentiam suam reditione completa'.

Those two examples show that Eckhart, although he explicitly cites Proclus, is implicitly referring to the Liber de causis (especially proposition Xv), in order to describe the dynamics of the intellect reverting onto itself. From this we can draw two provisional conclusions:

1) The explicit mention of Proclus in the Latin works is not an indication of a direct influence. At least in the cases discussed above, Proclus is always read through the lens of the Liber de causis and Thomas Aquinas.

2) This is particulary true for the question concerning the reversion of the intellectual substances onto themselves, a key theme in Eckhartian speculation. As I show presently, a particularly important role is played in this context by proposition XV of the Liber de causis, which Eckhart interprets in a very different way than Thomas Aquinas.

In the German Sermon 15, Homo quidam nobilis abijt in regione longiquam, Eckhart presents, in a rather faithful manner, the Aristotelian theory of the human

53 Meister Eckhart, Sermo LIV,2 n. 531, LW IV, p. 448,2.

54 Meister Eckhart, In Ioh. n. 222, LW III, p. 186,9. 
soul comparing it with his own opinion..$^{55}$ Meanwhile, he describes the movement of separate intelligences from and towards God; a theory which, although attributed to Aristotle, shows rather elements of Neoplatonism: ${ }^{56}$

Now attend carefully to what Aristotle says about the detached spirits in the book called Metaphysics. The highest of the masters who ever dealt with natural science speaks of these detached spirits, and says that they are not the form of anything, and that they derive their being by an immediate outpouring from God, and then they flow back in and receive the outpouring immediately from God, above the angels, and they gaze on the naked being of God without distinction. This pure naked being is called by Aristotle a 'something.' That is the highest that Aristotle ever declared concerning natural science, and no master can say greater things unless prompted by the Holy Ghost.

Niklaus Largier explains this passage as follows: ${ }^{57}$

Das Konzept der reinen abgeschiedenen Geister, d.h. der substantiae separatae von denen hier die Rede ist, geht auf neuplatonische Vorstellungen zurück, die an die aristotelische Annahme einer Vielzahl die Himmelkörper bewegender 'Beweger' anschließen, dieses Denkbild aber ontologisch neu formulieren (...). Eckhart identifiziert in den folgen Zeilen die reinen Geister mit den Engeln und folgt damit einer üblichen Tendenz der Scholastik.

Certainly, Largier is right when he explains that the separate spirits of which Eckhart speaks are the intelligences of Neoplatonism, who are often identified with the angels. He is wrong, however, when he claims that in this passage Eckhart equates the intelligences with the angels.

On the contrary, Eckhart explicitly says that these separated spirits are 'above the angels' (obewendic den engeln). In consequence, Eckhart is obviously referring to a theory that distinguishes angels from separate substances. I do not claim that this is Eckhart's personal opinion. I merely say that in this passage he describes a very precise cosmological system of intelligences whose being is determined by the movement of flowing out and returning to God.

55 See Beccarisi 2008, p. 15-16.

56 Meister Eckhart, Sermon 15 Q, DW I. English version by Walshe 2007, p. 272.

57 Largier 1993, I, p. 902. 
Propositions 31 and 32 of Proclus' Elements would be two likely candidates. ${ }^{58}$ But, as we have seen previously, Proclus does not seem to be a direct source for Eckhart. In this case, the reference to God and to the angels suggests that the direct source might be Dietrich of Freiberg. ${ }^{59}$ In his work De intellectu et intellegibili Dietrich clearly establishes a fourfold order in which intellectual reality stands: at the top of this order is found what Dietrich calls intellects existing through their essence, followed by intelligent spiritual substances that are called angels, then species and finally the individual realities included in species that are known to the mind. ${ }^{60}$ Therefore, according to Dietrich intelligences are not angels: angels are created immediately by God (productio), whereas intelligences flow from and return essentially to God (emanatio). ${ }^{61}$ Dietrich attributes the origin of this doctrine to Proclus, who had posited a relation of essential emanation or causation exercised by a prior upon its effect, which "converts in its essence toward that from which it proceeded":62

Proclus etiam dicit 31 propositione libri sui: 'Omne procedens ab aliquo secundum essentiam convertitur ad illud, a quo procedit.' Ubi dicitur in commento 4: 'Ad quod enim primo appetitus, ad hoc et conversio'. Et in commento 32 propositionis dicit: 'Quod enim convertitur omne ad omne copulari festinat et appetit communionem ad ipsum et colligationem ad ipsum.' (...) Secundum hoc igitur substantia, quae est intellectus per essentiam semper in actu, qualis est intellectus, de quo agitur, quia per essentiam intellectualiter procedit a Deo, etiam sua intellectuali operatione, quae est essentia eius, semper convertitur in Deum ita, ut eius emanatio, qua intellectualiter emanat per essentiam a suo principio, sit ipsius in ipsum principium intellectualis conversio. Non enim primo ab ipso procedit et postea alio respectu seu operatione in ipsum convertitur, sed eadem simplici intellectione, quae est essentia eius. In quo etiam differt ipsius talis emanatio et conversio ab emanatione et conversione aliarum rerum, quae secundum unum modum, scilicet quantum ad constitutionem suae substantiae, emanant a suo principio tamquam a causa

58 Proclus, Elementatio Theologica, prop. 31, p. 278 and prop. 32, p. 278.

59 See Flasch 1986, p. 125-134, and especially p. 125-127.

6o See https://plato.stanford.edu/entries/dietrich-freiberg/\#8.

61 Dietrich von Freiberg, De intellectu et intelligibili I 12, 144,6o-145,62: Est autem et hoc circa iam dicta tenendum, quod dicti philosophi loquentes de intelligentiis non loquebantur de angelis, de quibus scriptura sacra loquitur, quae loquitur mysteria abscondita a sapientibus et prudentibus et revelat ea parvulis, de angelis, inquam, quorum multa milia omnipotentia creatoris Dei immediate produxit, id est non secundum ordinem emanationis.

Dietrich von Freiberg, De visione beatifica I 5 (1). (4), p. 62, 41-45.63,58. 
efficiente, convertuntur autem in idem suum principium tamquam in finem per suas proprias operationes differentes a substantia sua. ${ }^{63}$

In Sermon 15 we find then a typical exemple of an Eckhartian mosaic, consisting of more or less explicit references. In the passage analyzed above we can trace references to Aristotle, Proclus, Dietrich, with which Eckhart presents precise cosmological and gnoseological doctrines: (1) the quidditative knowledge of the angels; (2) the Aristotelian system of separated substances; (3) Proclus' hierarchy of intelligences above the angels, which is also shared by Dietrich of Freiberg in his De visione beatifica and De intellectu et intelligibili.

Against this complex of doctrines attributed in Sermon 15 to the authority of Aristotle, Eckhart opposed his own theory of knowledge, exemplified by the metaphor of the noble man.

The noble man is not contented with quidditative knowledge, just as the angels: only the 'One' satisfies him: ${ }^{64}$

I say, however, that this noble man is not satisfied with the being that the angels cognize without form and depend on without means- - he is satisfied with nothing less than the solitary One.

But who is this noble man and what are his characteristics? Eckhart claims: ${ }^{65}$

A rational man is one who understands himself rationally, and is, in himself, detached from all matter and form. The more he is detached from all things and turned in on himself, the more clearly and rationally he knows all things within himself without turning outward, the more he is a man.

The intellectual experience which man makes of himself, the knowledge of himself and of all things around him, also determine his humanity. It is therefore a self-determination based on an intellectual experience that man makes of himself. It is not determined by external things, but by himself. It is a selfdetermination as "self-knowledge".

In this inner way, however, man does not discover himself as an individual, but rather as mankind per se: for in God he recognizes not only his own belong-

63 Dietrich von Freiberg, De visione beatifica 1.5. 4.6, p. 62,41-63,56.

64 Meister Eckhart, Sermon 15, DW I, p. 251, 13-15. English version by Walshe in Walshe, McGinn 2007, p. 272-273.

65 Meister Eckhart, Sermon 15, DW I, p. 250, 6-10. English version by Walshe in Walshe, McGinn 2007, p. 
ing to mankind, but humanity itself, as it really is, beyond its individual and particular phenomena.

In Sermon 15, therefore, we find the dynamics described in Sermon 9: as a non-material and intellectual substance, human mind return upon himself and find in himself the knowledge of himself and all things, just like God. ${ }^{66}$

The autority (the source) is not Proclus, which Eckhart tacitly criticizes, but rather the Liber de causis, as one of the characteristics of the nobleman demonstrates, namely 'simplicity', the indivisible, uncompounded and unfragmented wholeness of the Divine: 67

Now I say, How can it be that detachment of the understanding comprehends all things within itself without form or image, without turning outward or transforming itself? I say it comes from simplicity, for the more pure and simple a man is of himself in himself, the more simply he will understand all multiplicity in himself, while himself remaining immutable.

Although it was not recognized by the editor Joseph Quint, it seems to me that here Eckhart is referring, in an implicit but clear way, to propositions XV of the Liber de causis: ${ }^{8}$

Omnis sciens qui scit essentiam suam est rediens ad essentiam suam reditione completa (...) Et non significo per reditionem substantiae ad essentiam suam, nisi quia est stans fixa per se (belibt unwandelber in im selber) (...) quoniam est substantia simplex (ainvaltikait) sufficiens per seipsam.

66 Unlike Eckhart for Thomas Aquinas "human self-knowledge is neither perfect nor direct (...) For embodied souls, it would appear from De veritate 10.0 and Summa theologiae 1.87 that there is no such thing a direct, intuitive self-knowledge. Instead, the mind my be said to know it self in particular by virtue of its self-presence, since the mind is its own principle; but universally, self-knowledge —in the sense of a scientia of the soul-requires a 'careful and suble' enquiry". See Corrigan, Still 2004, p. 4. Scarpelli Cory instead claims that "in choosing v2 in Super Librum 15, Aquinas has deliberately chosen a variant of prop. 15 that is at odds with his own theory of self-knowledge". Cf. Scarpelli Cory 2017, p. 218. However, as I previously have shown, Eckhart includes rather variant 1 of proposition 15. I argue that this implies two alternatives: either Eckhart was not aware of other variants for this proposition, or he deliberately chose variant 1 . On the ground of the first variant, only the knower, who knows himself, has the property to return to himself and this is precisely the meaning of Sermon 15.

67 Meister Eckhart, Sermon 15 Q, DW I. English version by Walshe in Walshe, McGinn 2007, p. 272.

68 Liber de causis, prop. XV 124 and 128, p. 79,50-51. p. 79,65-8o,69. 
In the Liber de causis, "every knower" who knows its own nature, returns upon itself. This reditio is possible because the intellectual substance is simplex and sufficiens per se ipsam. It determines itself by virtue of this reditio, which is a fundamental knowledge of itself.

So it seems to me that there can be no doubt that proposition $\mathrm{XV}$ of the Liber de causis is the implicit source of this important passage from German Sermon 15, in which Eckhart states his anthropology as self-determination and self-knowing. For this, however, a much more accurate and literal source can be found.

Commenting the verse In simplicitate cordis quaerite illum (Sap. 1,1), Eckhart affirms that the root and the foundation of the intellect is simplicity. ${ }^{69}$ The editor notes that Eckhart uses the noun simplicitas as a synonym for immaterialitas, a term that never appears in the Latin works. The editor thus recognizes the intention of the Dominican master, who, according to the law of reditio described in the Liber de causis, maintains that only the spiritual, immaterial substances have the property of returning to themselves.

But even more clearly than in both Sermons 9 and 15, Eckhart quotes the authority of the Liber de causis in the Sapientia commentary, in order to affirm that the intellect, thanks to its simplicity, redit super se reditione completa, and that thanks to this reditio the intellect knows itself and all things. The intellect as an intellect has the property of knowing itself through a dynamic of conversion. These dynamics are characteristic of all intellectual substances, God as well as men, and they are described in the terms of the reditio completa in connection with the Liber de causis. If one compares the two passages- the first from the Sermon 15, the second from the Sapientia Commentary-it appears that the direct source of the passage of the sermon is the one from the commentary:

In Sap. In simplicitate cordis quaerite illum

Ubi notandum quod sicut unum et ens convertibiliter se habent, sic simplicitas et intellectualitas. Radix enim prima et ratio intellectualitatis est simplicitas (Ich sprich es kum von siner ainvaltikait). Argumentum huius est: Primo quia 'simplex' et ipsum solum redit se toto super se totum ( $\sin$ selbes in im selber ist) 'reditione completa', et propter hoc- $\mathrm{ex}$ De causisest sciens se ipsum et omnia per essentiam (alle manigvaltikait in im selber verstat)

69 Meister Eckhart, In Sap., LW II, n. 5, p. 327,1. 
That means that only what is simple redit super se reditione completa and therefore knows itself and everything "by its essence" (per essentiam). Hence, what is not simple does not know itself and therefore does not return upon itself. This reading of prop. 15 is quite different from that of Thomas Aquinas. Eckhart stresses the importance of simplicity, that is, immateriality, not to demonstrate the ability of the human soul to separate from the body, but as a necessary condition for self-knowledge.

I would like to take this opportunity to mention another case from a text to which recently Markus Vinzent has drawn the attention of researchers. But I will limit myself to one aspect, namely the simplicity of the intellect as a condition for self-knowledge and self-determination.

As is well known, Franz Pfeiffer has published not only Eckhart's German sermons and treatises, but also proverbs attributed to Meister Eckhart, which form the third part of his edition. ${ }^{70}$ Pfeiffer printed Spr. $31-48$ from a manuscript in Giessen, supposedly lost; it came from the convent of the Premonstratensian nuns at Altenberg, and Pfeiffer dated it to the 14th century (Anonymus Altenbergensis). Denifle already saw that this is in part a free translation from Eckhart's Expositio libri Sapientiae. Josef Quint discovered almost the same stock of aphorisms in a later manuscript of the $15^{\text {th }}$ century from the former Charterhouse of Buxheim near Memmingen (Anonymus Buxheimensis) (Berlin, Ms. germ. fol. 986), ${ }^{71}$ an important document, attributed by Loris Sturlese to the circle of the so-called 'Cologne Eckhartists', that is to say, the circle of disciples of Meister Eckhart who put his texts in circulation to defend his image and his philosophy. ${ }^{72}$ Studying this manuscript, Josef Koch, one of the editors of Eckhart's Latin works, realized that this collection was, in fact, a fairly accurate and literal translation of parts of the Sapientia commentary. Consequently, he incorporated them in the critical apparatus of his edition of the Latin text.

In the meantime, the manuscript used by Pfeiffer reappeared (WartburgStiftung, Ms. 1361-50) and was presented at a symposium held in Erfurt. ${ }^{73}$ Markus Vinzent, who is currently studying this supposedly lost witness, has advanced the hypothesis that behind this anonymous compilator not an Eckhartist is hiding, but rather Eckhart himself, who translated and diffused large

70 Meister Eckhart. Predigten und Traktate, ed. Franz Pfeiffer (Leipzig: 1857; repr. Aalen: 1962).

71 See Gottschall 2012, p. 535 .

72 Sturlese 2007, p. 119-136, esp. p. 132.

73 See Vinzent 2017, p. 109-134; further fragments are preserved in a Munich manuscript (Cgm 5235). 
passages of his Wisdom commentary. I will not go into the details of this question, which is still under examination by the specialists.

I would like, however, to comment on a particular passage of this text that supports Vinzent's hypothesis. One of the rare sources that the anonymous translates and cites explicitly, although under the usual formula die heidenschen meister, is the Liber de causis and, more precisely, proposition XVII. I here compare the text of Wisdom with that of the anonymous, as transcribed by Pfeiffer. The passages in common are set in bold:

ed. Pfeiffer, III, n. 45

In der wîsheit buoche sô sprichet der wîse man alsô die êwige wîsheit vermac alliu dinc, dar umbe, wan si einic ist. Hier über so gît meister Eckhart eine rede unde sprichet sô ein dinc je einveltiger ist, ie kreftiger unde ie sterker ist. Unde diz brüeven wir dabî: wan ein dinc von vil stücken ist ze samene gemachet, des dinges kraft lît alzemale an der stücken. Als daz hûs gemachet ist von den wenden unde dem fundamente unde von dem dache, hier umbe sô lît alles des hûses kraft an den selben teilen; mer: möhte daz hûs von siner einerkeit haben die kraft, die ez hat von den wenden, so bedörfte ez der wende niht. Wan nu got ist daz einveltigste guot, daz sin mac und in dem alliu dinc ein sint, hierumbe sô vermac er alliu dinc, wan er ein ist. Unde sprechent ouch die heidenschen meister, daz ein ieglichiu kraft swenne si sich wite zerteilet, so wir si deste bloeder. Reht also ist ez ouch umbe die vernunft: swenne si sich zerteilet in manicvaldekeit der kreature, so wirt si deste bloeder unde deste krenker gegen gote. Mer: swenne diu vernunft sich lediget von den kreaturen und alle
In Sap., LW II, n. 156, p. 492

Sequitur secundum principale, scilicet quomodo ex hoc ipso, quod est una, 'omnia potest'. Nec enim posset, nisi esset una, multo minus posset omnia. Sciendum ergo quod quanto quid est simplicius et unitius, tanto est potentius et virtuosius, plura potens. Ratio est: omne enim compositum posse suum et virtutem trahit ab aliis ipsum componentibus. Patet igitur quod posse et virtus sunt composito, inquantum compositum, aliena, ipsis autem simplicibus sunt propria. Et hoc est quod volumus, quod quant quid simplicius, tanto potentius et virtuosius, potens in plura et super plura. Quod autem apud nos compositiora sunt perfectiora, non est contra nos, sed pro nobis. Hoc enim accidit ex eo, non quia compositiora-sic enim sunt posteriora et dependentia—, sed hoc accidit, quia plura sunt simplicia quae ipsum componunt. Quanto autem a pluribus virtus descendit in aliquid, tanto est ipsum virtuosius, plura potens. Resumendo ergo formetur ratio sic breviter: quanto quid unitius, tanto potentius, ut dictum est. Ergo quod est simpliciter unum-et 
(cont.)

sinne zesamen loufent in die vernunft unde da diu vernunft und ouch die sinne sich mit einander vereinent, so wirt di vernunft also kreftic, daz si überwindet got swes si von im begert. Wan swenne der mensche tuot, daz an im ist, sô mac sich got nihtes erwern. ipsum solum - potest omnia. Topicum est enim: si magis ad magis, et simpliciter ad simpliciter. Sed sapientia est una simpliciter, ut hic dicitur; ergo ipsa potest omnia. Et hoc est quod hic dicitur: 'cum sit una, omnia potest'. Praeterea secundo sic ex De causis: 'omnis virtus unita infinitior est', plura et in plura potens. Sed sapientia, quae deus est, est maxime una, utpote prima. Igitur ipsa est simpliciter infinita et omnia potens.

In this example too, both in the Latin version and in the text in German, simplicity is at the center of the discourse, this time as a condition of the omnipotence of Wisdom, which by virtue of its unity can do everything. Indeed, by implicitly citing proposition XVII, Eckhart affirms that the simpler the thing, the more powerful it is. Therefore, the One, that is, God, which is absolutely simple, can perform all things. Eckhart gives three demonstrations: one comes from Aristotle's Topics, the second from the Liber de causis and the last one is based on the dynamics of the pair form / act.

Compared to the Latin text, however, the German version adds two important elements. The first is precisely a citation from the Liber de causis. While the Latin text relates only the main proposition, the German text cites also the commentary:

Et illius quidem significatio est virtus divisa et quod ipsa, quanto magis agregatur et unitur, magnificatur et vehementior fit et efficit operationes mirabiles; et quanto magis partitur et dividitur minoratur et debilitatur et efficit operationes viles.

The second element to be noted is a reference to the activity of the intellect, described, as in the German Sermon 15, in its double attitude towards things: it is sometimes dispersed in multiplicity, sometimes turned towards itself, united and unique in itself, as God.

The Altenbergensis thus shows three facts. (1) It is the intellect as such, both divine and human, which, thanks to its simplicity, determines itself without any orientation to external things. The anonymous explicitly expresses this 
idea: if the intellect is united in itself and is separated from the diversity of the creatures, then it is so powerful that he even surpasses God in his action and forces God who cannot withhold himself (überwindet got swes is von im begert. Wan swenne der mensche tuot, daz an im ist, sô mac sich got nihtes erwern). (2) The interpretation of the Liber de causis which translates the Wisdom Commentary while at the same time taking it further by being close to German Sermon 15 is hardly a work of an Eckhartist, but displays the systematic thinking of Eckhart himself. (3) That is why we can speak of Eckhart's own theory of self-determination which is developed here, clearly influenced by the Liber de causis, especially by the propositions in which the reditio of the intellect is described.

\section{5}

\section{Conclusions}

We can thus draw the following conclusions:

1) Proclus had, for Eckhart, an importance certainly inferior to that which some scholars have attributed to him. In any case, this importance is inferior to that which Proclus has had for Tauler or Berthold von Moosburg. Alain de Libera ${ }^{74}$ seems right when he affirms that we read Eckhart after equations and identifications produced not by him, but by Tauler or Berthold von Moosburg. We are asking Eckhart the very same questions already posed to him by Tauler and Berthold.

2) A second conclusion concerns the difference between Scholasticism and mysticism, between the ontology of Latin texts and the Henology of the texts in the vernacular. The cases that I have presented as examples tend to show an influence not only thematically, but also textually, between Eckhart's academic, homiletic and lecturing outputs. The difference is not in their content, but rather in tone, in the use of examples, in the freedom with which Eckhart handles his sources.

3) This in turn leads us to the third conclusion: we should not exclude, as certain examples already pointed out show, that Eckhart himself translated part of his Latin work into German, reshaping, broadening or specifying some sources used in his academic output. The case of Sermon 15 might confirm Markus Vinzent's thesis, according to which the author of the translation of passages from the Sapientia commentary (the so called Anonymus Altenbergensis) was Eckhart himself. 


\section{Bibliography}

\section{Manuscripts Consulted}

Berlin, Staatsbibliothek, Ms. germ. fol. 986

Eisenach, Bibl. der Wartburg-Stiftung, Ms. 1361-50

Munich, Bayerische Staatsbibliothek, Cgm 5235

\section{Primary Sources}

Liber de causis - A. Pattin, "Le Liber de causis. Édition établie à l' aide de 90 manuscrits avec introduction et notes", in Tijdschrift voor Filosofie 28 (1966), p. 90-203; repr. dans A. Pattin, Miscellanea. I. Liber de causis, Leuven, Bibliotheek van de Faculteit der Godgeleerdheid, 200o. The Book of Causes: Liber de causis (1984), eds B.C. Bazán and D.J. Brand, Milwaukee, Marquette University Press.

Albert the Great, De causis et processu universitatis a prima causa, ed. W. Fauser, Müster, Aschendorff, 1993.

Dietrich von Freiberg, Opera omnia. Schriften zur Intellekttheorie, ed. B. Mojsisch, Hamburg, Feliz Meiner Verlag, 1977.

Meister Eckhart, Predigten und Traktate, ed. F. Pfeiffer, Leipzig, Aalen, 1857 (repr. 1962). Meister Eckhart, Le 64 prediche sul tempo liturgico. Testo alto-tedesco medio a fronte, ed. L. Sturlese, Milano, Bompiani, 2014.

Meister Eckhart, Die deutschen und die lateinischen Werke, herausgegeben im Auftrag der Deutschen Forschungsgemeinschaft. Die deutschen Werke, eds J. Quint and G. Steer, Stuttgart, Kohlhammer, 1936 f. Die deutsche Werke I, ed. J. Quint, Stuttgart, Kohlhammer, 1958. Die lateinische Werke, ed. J. Koch, Stuttgart, Kohlhammer, 1936.

Ps.-Eckhart, Tr. XI.2, in ed. F. Pfeiffer, Deutsche Mystiker des vierzehnten Jahrhunderts, Bd. 2: Meister Eckhart. Predigten und Traktate, Leipzig 1857, unveränderter Nachdruck, Aalen 1962.

Thomas Aquinas, Super Librum de Causis expositio, ed. H.D. Saffrey, Fribourg, Louvain Société Philosophique, Editions E. Nauwelaerts, 1954.

\section{Secondary Sources}

Bauchwitz, O.F. (2016), "Homo quidam erat dives: lectura del sermón 8o del Maestro Eckhart a la luz del Liber de causis", in Revista Española de Filosofía Medieval 23, p. 291-298.

Baumgarten, A. (2014), "Reditio completa. Connaissance et réflexivité dans quelques commentaires latins sur le Livre des causes", in Transylvanian Review 23, p. 23-47.

Beccarisi, A. (2003), "Philosophische Neologismen zwischen Latein und Volksprache: istic und isticheit bei Meister Eckhart”, in Recherches de théologie et philosophie médiévales 7o, p. 328-358. 
Beccarisi, A. (2016), "Zwischen Averroes, Avicenna und Avicebron. Meister Eckhart und die Noetik im Islam und Judentum", in Meister Eckhart Jahrbuch 10, p. 223240.

Beccarisi, A. (2019), Sicut Albertus saepe dicebat. Albertus Magnus und Meister Eckhart, Münster, Aschendorff.

Beierwaltes, W. (1965), Proklos: Grundzüge seiner Metaphysik, Frankfurt am Main, Klostermann.

Beierwaltes, W. (1972), Platonismus und Idealismus, Frankfurt am Main, Klostermann. Beierwaltes, W. (1998), Platonismus in Christentum, Frankfurt am Main, Klostermann. Bertolacci, A. (1998), "Subtilius speculando. Le citazioni della Philosophia prima di Avicenna nel Commento alla Metafisica di Alberto Magno", in Documentie studi sulla tradizione filosofica medievale 9, p. 261-339.

Calma D. (2009), “L'usage des statistiques dans l' étude des sources: le cas de Maître Eckhart", in Freiburger Zeitschrift für Philosophie und Theologie 56, p. 526-531.

Calma D. (2010), Le poids de la citation. Étude sur les sources arabes et grecques dans l'œuvre de Dietrich de Freiberg, Fribourg, Academic Press Fribourg.

Calma D. (2012), "Du néoplatonisme au réalisme et retour. Parcours latins du Liber de causis aux XIII ${ }^{\mathrm{e}}-\mathrm{XVI}{ }^{\mathrm{e}}$ siècles", in Bulletin de philosophie médiévale 54, p. 217-276.

Corrigan, K., Still, C.N. (2004), "The Problem of Aquinas's Notion of reditio completa in Relation to its Neoplatonic Sources", in J.M. Hackett, W.E. Murnion, C.N. Still (eds), Being and Thought in Aquinas, Binghamton (NY), Global Academic Pub.

Di Segni, D. (2012), "verba sunt Rabbi Moysis: Eckhart e Maimonide", in L. Sturlese (ed.), Studi sulle fonti di Meister Eckhart. II, Fribourg, Academic Press, 2012, p. 103140.

Enders, M. (2012), "Meister Eckhart's understanding of God", in J. Hackett (ed.), A Companion to Meister Eckhart, Leiden / Boston, Brill, p. 359-388.

Flasch, K. (1986), "Procedere ut imago. Das Hervorgehen des Intellekts aus seinem göttlichen Grund bei Meister Dietrich, Meister Eckhart und Berthold von Moosburg", in K. Ruh (ed.), Abendländische Mystik im Mittelalter (Symposion Kloster Engelberg 1984), Stuttgart, Kohlhammer, p. 125-134.

Flasch, K. (2007), Dietrich von Freiberg. Philosophie, Theologie, Naturforschung um 1зо0, Frankfurt am Main, Vittorio Klostermann.

Geyer, B. (1964), "Albertus Magnus und Meister Eckhart", in H. Moser u. a. (eds), Festschrift für Josef Quint anläßlich seines 65. Geburtstages überreicht, Bonn, E. Semmel, p. 121-126.

Goris, W. (1997), Einheit als Prinzip und Ziel. Versuch über die Einheitsmetaphysik des Opus tripartitum Meister Eckharts, Leiden, Brill.

Goris, W. (2009), “The Unpleasantness with the Agent Intellect in Meister Eckhart", in S.F. Brown, T. Dewender, Th. Kobusch (eds), Philosophical Debates at Paris in the Early Fourteenth Century, Leiden / Boston, Brill, p. 151-159. 
Gottschall, D. (2012), "Eckhart's German Works", in J.M. Hackett (ed.), Companion to Meister Eckhart, Leiden / Boston, Brill, p. 137-184.

Gottschall, D. (2015), "Mystische Reimverse mit Kommentar. Eine bisher übersehene Fortsetzung zu Ein meister der seit vns das wesen blos", in Beiträge zur Geschichte der deutschen Sprache und Literatur 137/1, p. 80-107.

Hedwig, K. (1980), "Negatio negationis. Problemgeschichtliche Aspekte einer Denkstruktur", in Archiv für Begriffsgeschichte 24, p. 7-33.

Largier, N. (1993), "Kommentar", in N. Largier (ed.), Meister Eckhart, Werke. Texte und Übersetzungen, vol. 2, Frankfurt a.M., Deutscher Klassikerverlag, 1993.

Libera, A. de (1996), Suso, Tauler ou la divinisation de l'homme, Paris, Bayard.

Libera, A. de (1990), "Uno, unione e unità in Meister Eckhart: dall'uno trascendentale all'Uno trascendente", in V. Melchiorre (ed.), L'Uno e i molti, Milano, Vita e Pensiero, p. 249-282.

Meliadò, M. (2013), "Theologie und Noetik der Erstursache: der Liber de causis als Quelle Meister Eckharts", in Documenti e Studi sulla Tradizione Filosofica Medievale 24, p. 501-553.

Putallaz, F.-X. (1991), Le sens de la réflexion chez Thomas d'Aquin, Vrin, Paris.

Retucci, F. (2008), "Her ûf sprichet ein heidenischer meister in dem buoche, daz dâ heizet daz lieht der liehte": Eckhart, il Liber de causis e Proclo", in Sturlese 2008, p. $135^{-166 .}$

Retucci, F. (2012), "úber das so enmag kain maister hoeher gesprechen: Eckhart e la Metafisica di Aristotele", in L. Sturlese (ed.), Studi sulle fonti di Meister Eckhart. II, Fribourg, Academic Press., p. 11-37.

Ruh, K. (1996), Geschichte der abendländischen Mystik, II I: Die Mystikdes deutschen Predigerordens und ihre Grundlegung durch die Hochscholastik, München, Beck, p. 19$3^{2 .}$

Scarpelli Cory, T. (2017), "Reditio completa, reditio incompleta: Aquinas and the Liber de causis, prop. 15, on Reflexivity and Incorporeality", in A. Fidora, N. Polloni (eds), Appropriation, Interpretation and Criticism: Philosophical and Theological Exchanges between the Arabic, Hebrew and Latin Intellectual Traditions, Porto, FIDEM, p. 185229 .

Steel C. (2006), "Proklos über Selbstreflexion und Selbstbegründung", in M. Perkams, R.M.Piccione (eds), Proklos. Methode, Seelenlehre, Metaphysik, Leiden / Boston, Brill, p. $230-255$.

Steel C. (1999), "Negatio negationis. Proclus on the Final Lemma of the First Hypothesis of the Parmenides", in J.J. Cleary (ed.), Traditions of Platonism. Essays in honour of John Dillon, Farnham, Ashgate, p. 351-368.

Sturlese, L. (2007), "Die Kölner Eckhartisten. Das Studium generale der deutschen Dominikaner und die Verurteilung der Thesen Meister Eckharts", in Id. (ed.), Homo divinus, Stuttgart, Kohlhammer, p. 119-136. 
Sturlese, L. (2008) (ed.), Studi sulle fonti di Meister Eckhart. I: Aristoteles-Augustinus -Avicenna-Dionysius_Liber de causis_Proclus_Seneca, Fribourg, Academic Press Fribourg.

Sturlese, L. (2014), Meister Eckhart, Le 64 Prediche sul tempo liturgico, a cura di L. Sturlese, Roma, Bompiani.

Suarez Nani, T. (2002), Connaissance et language des anges selon Thomas d'Aquin et Gilles de Rome, Paris, Vrin.

Tsopurashvili, T. (2012), "The Theory of the Transcendentals in Meister Eckhart", in J. Hackett (ed.), A Companion to Meister Eckhart, Leiden / Boston, Brill, p. 185-204. Vinzent, M. (2012), The art of the Detachment, Leuven, Peeters.

Vinzent, M. (2014), “Original, Zitat, Plagiat? Meister Eckharts Auffassung von Quellen”, in Meister Eckhart Jahrbuch 7, p. 105-122.

Vinzent, M. (2017), "Meister Eckhart's Self-translations into the Vernacular", in Bulletin de philosophie médiévale 59, p. 109-134.

Vinzent, M., Sturlese, L. (2019), Meister Eckhart, The German Works: 64 Homilies for the Liturgical Year. 1. De tempore. Introduction, Translation and Notes, Leuven, Peeters Publisher.

Walshe, M. O'C., McGinn, B. (2007), The Complete Mystical Works of Meister Eckhart, New York, The Crossroad Publishing Company. 